\title{
Challenges and benefits of building sustainable cooperative housing
}

José Coimbra (corresponding author)

Email: josepaulocoimbra@gmail.com

Tel.: +351229519288; Fax: +351229578356.

University of Minho, School of Engineering, Department of Civil Engineering, Campus de Azurem, 4800-058 Guimaraes, Portugal

Manuela Almeida

Email: malmeida@civil.uminho.pt

University of Minho, School of Engineering, Department of Civil Engineering, Campus de Azurem, 4800-058 Guimaraes, Portugal

\begin{abstract}
This research has the goal of determining, comparing and substantiating the actual outcome of using sustainable practices, from a financial and environmental comfort point of view. The selected context was of interest due to the challenge of quality sustainable construction at controlled costs, meant for inhabitants of the Portuguese cooperative housing, due to its economical implications and especially its social ones. Two case studies of cooperative housing developments built in Portugal are presented, the first with characteristics of traditional construction and the second including sustainable building features. With these examples, it is intended to demonstrate that it is possible to build below cost limits imposed by law in order to substantially reduce energy consumption costs for heating and cooling as well as for domestic water heating. So, calculations of energy savings in indoor heating and cooling, as well as for domestic water heating are presented in this article for two specific situations: first, for a standard comfort use of housing, as opposed to a situation of real consumption of housing developments as obtained by monitoring carried out for one year in the same dwellings studied for standard comfort. The causes that lead to a substantial decrease in energy consumption in the building of sustainable construction are also described, as a starting point to the improvement of future cooperative housing. Finally are presented, for each of the two situations, calculations of the payback period of investment, according to the specific incremental cost in sustainable construction and the benefits in reducing consumptions. The results show an effective contribution to the improvement of the environment and environmental comfort, due to sustainable construction.
\end{abstract}

Keywords: cooperative housing, sustainable construction, controlled costs, energy efficiency.

\section{Introduction}

From the beginning of this century, changes in global climate, depletion of natural resources, pollution and economic crisis have become unsustainable [1]. The imperative of changing practices became immediate, spurred by the consistent increases in energy and natural resources costs, such as petrol, gas and domestic water [2]. In Portugal, cooperative residents, coming from middle class and lower-middle class families, have an increasing difficulty in paying running costs of their own housing due to the strong economic downturn that has plagued Europe and the United States, the rising cost of living, their low incomes or even unemployment and the difficult access to social security [3]. On the other hand, cooperative families do not live, in general, in households with low energy consumption and do not enjoy comfortable housing from an environmental point of view. So, it is necessary to 
conceive, design and follow new directions, in order to overturn these negative conditions, and so (re)configure a product both economically and socially sustainable and obtainable [4, 5].

Therefore, it becomes important to evaluate how cooperative housing can be energetically efficient and environmentally sustainable, decreasing running costs during its life cycle and thus fitting itself to the actual decrease of its inhabitants' income and to the increase of energy and natural resources costs. Complementary, this study also includes an approach in which cooperative housing may contribute to the decrease of environmental impact, in comparison to traditional construction. These two main goals are presented in such a way that this improvement only implies a small increase of the construction cost, payable in a short payback period. This small increase of cost due to sustainable construction becomes relevant, knowing that low and middle class families can't afford, for the same reasons, obtaining an expensive residence.

In this context, the main challenge of this research work is the assessment of sustainable construction solutions under following Portuguese legislation of construction cost limits, through the study of two cases in what concerns construction and use of cooperative housing, to be followed in new projects, and determining their actual benefits in economic and environmental terms.

\section{Challenges of energy efficiency in cooperative housing}

European and Portuguese Directives, including Directive 2002/91/EC on the Community Energy Performance of Buildings and Energy Certification requirement of new and existing buildings [6, 7, 8], have contributed to the increased responsibility of developers, builders, owners and residents. Since the construction activity uses a large part of the planet's natural resources, a major agreement is essential to replace non-renewable, non-self-sufficient resources and materials, as well as saving energy and reducing $\mathrm{CO}_{2}$ emissions to the atmosphere [2]. The buildings can and should generate their own energy, receive and reuse their own water, use recycled materials and compensate the emission of $\mathrm{CO}_{2}$ in the production of the construction materials.

Most sustainable construction solutions in buildings are constrained by excessive costs or by very limited choice possibilities for quality and, at the same time, low cost construction solutions [9, 10]. However, a deeper understanding of the costs and techniques used in the operation of energy efficient systems and their impact on social and economic savings of economic resources in families who live in cooperative housing over the life of the building is starting to be developed [11].

This knowledge of the economic benefits of sustainable buildings [5], as well as the idea of creating sustainable cooperative housing, was brought about due to the fact that, over the years, the cooperative sector has drawn up and synthesized a set of rules designed to form a particular organization model and optimize cooperative activity and social responsibility, including standards-based quality management $[3,12]$.

The adopted management model has emerged, amongst other factors, as a need to respond adequately to the two main conditions for the cooperative sector in Portugal $[3,11,13]$ :

- The cooperative housing product is targeted to families of medium or medium-low financial income, mostly made up of young couples who are eager for households with high standards of quality and superior design, space and building systems with more efficient equipment. Moreover, in purchasing cooperative housing, these families can achieve a house at a price $50 \%$ to $70 \%$ lower than the current real estate market, while, at the same time, being able to follow current trends in the design and construction; 
- Social housing cooperatives have tax benefits provided by law [14] as long as their housing projects comply with the technical and legal rules of social housing. These rules, which are official and supervised by IHRU - Institute for Housing and Urban Renovation, with its headquarters in Lisbon, impose maximum areas and maximum costs of construction for dwellings which provide tax benefits to construction.

However, cooperative housing, as well as general real estate housing in Portugal, is nowadays facing an increasing demand of regulatory compliance with standards of safety, efficiency, quality and functionality in homes, which translates in a substantial increase in cost of construction per square meter, although maximum areas and maximum costs remain unchanged [9]. Thus, the management of building construction by cooperatives is increasingly more difficult and therefore increasingly reduced.

Nevertheless, the use of sustainable construction solutions brings an increased investment into the overall cost of the project, thus increasing the selling price of the dwellings. However, bearing in mind that the maximum cost of sale cannot be exceeded, there is a need to carefully manage the construction solutions to be adopted, using only those that fall within the acceptable costs. As a result, the cost of sustainable cooperative housing will be higher than traditional cooperative housing in $5 \%$ to $8 \%$ (numbers based on a recent assessment report of the payback period of sustainable construction in cooperative housing [15]) thus, putting the construction costs near the official limits though still feasible.

From this stage onwards, the management of cooperative housing projects must consider three new aspects:

- Although it is mandatory to comply with the official costs, it is possible to use high-efficient building systems and equipment [15];

- These high-efficient building systems and equipment will assure a reduction on the running costs in what concerns consumption of gas and electricity for water and heating;

- Lower consumption of gas and electricity lead to lower $\mathrm{CO}_{2}$ emissions to the atmosphere, so environmental impact will diminish.

\section{Methodology}

It is the purpose of this work to realize how to design sustainable cooperative housing within the limits of costs and areas, using a case study methodology, in cooperative building construction, in the district of Porto. Therefore, this paper presents a comparative case study, which involves specific and detailed analysis of two buildings, selected to represent sustainable and traditional cooperative housing. The buildings have different decades of construction, but have similar locations and the same climatic zone, for better comparison.

A total of sixty five dwellings were assessed during one full year. By collecting and processing data of existing projects, the savings in electricity and natural gas of sustainable cooperative housing, in comparison with the traditional housing ones, will be quantified.

It will be shown that there is an effective contribution to improvement of environmental respect and environmental comfort, which results from the benefits obtained by using energy efficient building systems, taking into account running costs, maintenance costs and environmental comfort.

\section{Buildings characteristics}

To quantify the annual savings (cost reduction in consumption of electricity and natural gas) of the residents of cooperative housing in dwellings with sustainable characteristics when compared to the 
same costs supported by the inhabitants of traditional cooperative dwellings, a study is presented comparing two cooperative housing settlements in the district of Porto. One is located in the city of Matosinhos $\left(41.200631^{\circ} \mathrm{N}, 8.698134^{\circ} \mathrm{W}\right)$ and the other in the city of Senhora da Hora $\left(41.182666^{\circ} \mathrm{N}\right.$, $\left.8.665556^{\circ} \mathrm{W}\right)$. The first settlement was designed and built following sustainable and energy-efficient construction principles in $2007 / 2008$. The second one was built in the early 1990s, according to the usual features at the time for the construction of traditional cooperative housing. The studies carried out show the energy efficiency of each dwelling in the two settlements with the quantification of the energy demand (electricity for space heating and natural gas for water heating) and related costs in order to compare the effort borne by the residents.

\subsection{Description of the building Leça, Matosinhos}

The building of Leça consists of a tenement building located in the city of Matosinhos, containing twenty-nine dwellings, seventeen with three bedrooms, ten with two bedrooms and two with one bedroom. It is placed in the inner urban zone at an altitude of $33 \mathrm{~m}$, a distance to coast of $2 \mathrm{~km}$ and the dwellings are developed in five floors, facing north and south. The area of façades, without glazing, is of $467.00 \mathrm{~m}^{2}\left(61.5 \%\right.$ of total façade area) and the area of glazing is $293.00 \mathrm{~m}^{2}(38.5 \%)$. All of them have strong thermal inertia, with thermal insulation in all exterior walls and in walls in contact with non-heated spaces and have no central heating or cooling systems, only portable heaters. All dwellings have a mechanical ventilation system as well as a domestic water heating system that consists of gas heaters and solar collectors.

\subsection{Description of the building Azenha de Cima, Senhora da Hora}

The building of Azenha de Cima consists of a tenement building located in the city of Senhora da Hora, containing thirty six dwellings, twenty dwellings with two bedrooms, twelve with three bedrooms and four with four bedrooms. It is located inside the urban area, at an altitude of $50 \mathrm{~m}$ and a distance to coast of $2 \mathrm{~km}$ and the dwellings are developed in four floors, towards north, east and west. The area of façades, without glazing, is of $1,033.00 \mathrm{~m}^{2}(75.2 \%$ of total façade area) and the area of glazing is $341.00 \mathrm{~m}^{2}(24.8 \%)$. All of them have strong thermal inertia, have no insulation in any part of the envelope, they have also no central heating or cooling systems, only portable heaters. Domestic hot water is produced with a 20-year old, low-efficient, gas heater and no solar collectors are installed.

\subsection{Description of the housing envelope and mechanical systems}

For the purpose of quantification and comparison of the numeric results of energy efficiency and energy demands of the dwellings, tables with information of all of them were prepared describing the envelope - façades, inner walls (walls separating heated spaces from non-heated spaces), external and interior pavements (pavements separating heated spaces from non-heated spaces), roofs and floors, glazing and shading devices), ventilation systems, heating and cooling equipment, solar collectors and hot water systems, respectively in Leça, Table 1, and in Azenha de Cima, Table 2.

Tables 1 and 2 show, for each envelope described, its thermal transmittance $\left(\mathrm{W} / \mathrm{m}^{2} .{ }^{\circ} \mathrm{C}\right)$. It is also shown the annual solar energy produced by solar collectors $(\mathrm{kWh})$, efficiency of gas heaters and airflow rate of mechanical ventilators $\left(\mathrm{m}^{3} / \mathrm{h}\right)$. Solar collectors used in the Leça building are in accordance with standard norms EN 12975 and also follow specific Keymark rules for solar thermal products. Solar collectors were chosen according to quality criteria concerning tubes and headers in the collector, materials of the absorber plate and insulation of sides and back of the solar collector [20]. 
Thermal transmittance calculations shown in Tables 1 and 2 were based on thermal conductance and thermal resistance of the aforementioned materials [16, 17, 18].

Insulation thickness was optimized according to the degree-hours in location of the case study, as used with positive results in other cooperative sustainable projects [19].

Table 1 - Description of the housing envelope and equipment - Leça

\begin{tabular}{|c|c|c|}
\hline $\begin{array}{l}\text { Envelope / } \\
\text { Equipment }\end{array}$ & Description & $\begin{array}{l}\text { Thermal } \\
\text { transmittance / } \\
\text { efficiency }\end{array}$ \\
\hline North Façade & $\begin{array}{l}\text { Double pane wall, dark-coloured cored brick with } 11 \mathrm{~cm} \text { and hollow } \\
\text { brick with } 15 \mathrm{~cm} \text {, with } 4 \mathrm{~cm} \text { of XPS }\end{array}$ & $0.53 \mathrm{~W} / \mathrm{m}^{2}{ }^{\circ} \mathrm{C}$ \\
\hline South Façade & $\begin{array}{l}\text { Single pane wall, hollow brick with } 20 \mathrm{~cm} \text {, with } 5 \mathrm{~cm} \text { of PUR, light- } \\
\text { coloured } 16 \mathrm{~mm} \text { HPL panels (High Pressure Laminate) }\end{array}$ & $0.61 \mathrm{~W} / \mathrm{m}^{2}{ }^{\circ} \mathrm{C}$ \\
\hline Inner walls & $\begin{array}{l}\text { Double pane wall, solid brick with } 11 \mathrm{~cm} \text { and hollow brick with } 11 \mathrm{~cm} \\
\text { with } 4 \mathrm{~cm} \text { of Mineral Wool }\end{array}$ & $0.58 \mathrm{~W} / \mathrm{m}^{2}{ }^{\circ} \mathrm{C}$ \\
\hline $\begin{array}{l}\text { Thermal } \\
\text { bridges }\end{array}$ & $\begin{array}{l}\text { Double pane wall, cored brick with } 11 \mathrm{~cm} \text { and concrete with } 20 \mathrm{~cm}, \\
\text { with } 4 \mathrm{~cm} \text { of XPS / PUR }\end{array}$ & $0.78 \mathrm{~W} / \mathrm{m}^{2}{ }^{\circ} \mathrm{C}$ \\
\hline $\begin{array}{l}\text { Exterior } \\
\text { pavement }\end{array}$ & $\begin{array}{l}\text { Dropped ceiling of plaster panels, pre-stressed concrete "T" beams } \\
\text { with lightweight expanded clay aggregate (LECA) } 24 \mathrm{~cm} \text { thick, } 8 \mathrm{~cm} \\
\text { concrete layer, } 1 \mathrm{~cm} \text { of polyethylene foam, } 4 \mathrm{~cm} \text { regularization layer }\end{array}$ & $0.99 \mathrm{~W} / \mathrm{m}^{2}{ }^{\circ} \mathrm{C}$ \\
\hline $\begin{array}{l}\text { Interior } \\
\text { pavement }\end{array}$ & $\begin{array}{l}\text { Dropped ceiling of plaster panels, pre-stressed concrete "T" beams } \\
\text { with lightweight expanded clay aggregate (LECA) } 24 \mathrm{~cm} \text { thick, } 4 \mathrm{~cm} \\
\text { light-weight EPS and concrete layer, } 1 \mathrm{~cm} \text { of polyethylene foam, } 4 \mathrm{~cm} \\
\text { regularization layer }\end{array}$ & $1.21 \mathrm{~W} / \mathrm{m}^{2}{ }^{\circ} \mathrm{C}$ \\
\hline $\begin{array}{l}\text { Horizontal } \\
\text { roof }\end{array}$ & $\begin{array}{l}\text { Pre-stressed concrete "T" beams with lightweight expanded clay } \\
\text { aggregate (LECA) } 25 \mathrm{~cm} \text { thick, } 10 \mathrm{~cm} \text { light-weight EPS and concrete } \\
\text { layer, } 6 \mathrm{~cm} \text { XPS, } 4 \mathrm{~cm} \text { regularization layer, flexible PVC membrane }\end{array}$ & $0.33 \mathrm{~W} / \mathrm{m}^{2}{ }^{\circ} \mathrm{C}$ \\
\hline Glazing & $\begin{array}{l}\text { Glazed anodized aluminum frames without thermal break, weather- } \\
\text { proof, double-glazed } 8+8+8 \text {, with white-colored PVC outdoor blinds }\end{array}$ & $3.00 \mathrm{~W} / \mathrm{m}^{2}{ }^{\circ} \mathrm{C}$ \\
\hline Ventilation & $\begin{array}{l}\text { Mechanical ventilation that consists of common extractors installed } \\
\text { on the roof, with constant flow }\end{array}$ & $\begin{array}{l}\text { Airflow rate of } \\
100 \mathrm{~m}^{3} / \mathrm{h}\end{array}$ \\
\hline Space heating & Manual or portable electric heaters & Efficiency $=1$ \\
\hline $\begin{array}{l}\text { Domestic Hot } \\
\text { Water (DHW) } \\
\text { preparation } \\
\text { system }\end{array}$ & $\begin{array}{l}\text { Collective set of solar collectors CPC AoSol (aperture area }=1,98 \mathrm{~m}^{2} \text {, } \\
\left.\text { efficiency } \eta_{0}=0,726, \mathrm{a}_{1}=3,7 \mathrm{~W} / \mathrm{m}^{2} / \mathrm{K}, \mathrm{a}_{2}=0,014 \mathrm{~W} / \mathrm{m}^{2} / \mathrm{K}^{2}\right) \text {, facing } \\
\text { South, inclination of } 45^{\circ} \text { and indoor storage tank with collective } \\
\text { support of DHW preparation system that consists of Junkers heater } \\
\text { WT 14AM } 14 \text { liters sealed, with an efficiency of } 0.78\end{array}$ & $\begin{array}{r}\text { Solar energy } \\
\text { of } 1,277(\mathrm{~T} 3) \text {, } \\
958(\mathrm{~T} 2) \text { and } \\
638(\mathrm{~T} 1) \mathrm{kWh} \\
\text { per year. }\end{array}$ \\
\hline & $\begin{array}{ll}\text { ne rigid foam } & \text { XPS - expanded extruded polystyrene }\end{array}$ & \\
\hline
\end{tabular}

Table 2 - Description of the housing envelope and equipment - Azenha de Cima

\begin{tabular}{|c|c|c|}
\hline $\begin{array}{l}\text { Envelope / } \\
\text { Equipment }\end{array}$ & Description & $\begin{array}{r}\text { Thermal transmittance } \\
\text { / efficiency }\end{array}$ \\
\hline Façades 1 & $\begin{array}{l}\text { Double pane wall, brick with } 11 \mathrm{~cm} \text { and hollow brick with } 11 \mathrm{~cm} \text {, no } \\
\text { insulation }\end{array}$ & $1.11 \mathrm{~W} / \mathrm{m}^{2}{ }^{\circ} \mathrm{C}$ \\
\hline Façades 2 & $\begin{array}{l}\text { Double pane wall, concrete wall with } 15 \mathrm{~cm}, 4 \mathrm{~cm} \text { air gap and hollow } \\
\text { brick with } 11 \mathrm{~cm} \text {, no insulation }\end{array}$ & $1.47 \mathrm{~W} / \mathrm{m}^{2} .{ }^{\circ} \mathrm{C}$ \\
\hline Inner walls 1 & $15 \mathrm{~cm}$ hollow brick (in contact with the lift box) & $1.47 \mathrm{~W} / \mathrm{m}^{2} .{ }^{\circ} \mathrm{C}$ \\
\hline Inner walls 2 & $\begin{array}{l}\text { Double pane wall, concrete wall with } 15 \mathrm{~cm}, 4 \mathrm{~cm} \text { air gap, and hollow } \\
\text { brick with } 11 \mathrm{~cm} \text {, no insulation (in contact with staircase and lift box) }\end{array}$ & $1.28 \mathrm{~W} / \mathrm{m}^{2} .{ }^{\circ} \mathrm{C}$ \\
\hline $\begin{array}{l}\text { Thermal } \\
\text { bridges }\end{array}$ & $\begin{array}{l}\text { Double pane wall, brick with } 11 \mathrm{~cm} \text { and } 20 \mathrm{~cm} \text { thick concrete } \\
\text { structure, no insulation }\end{array}$ & $2.09 \mathrm{~W} / \mathrm{m}^{2} .{ }^{\circ} \mathrm{C}$ \\
\hline $\begin{array}{l}\text { Exterior } \\
\text { pavement }\end{array}$ & $\begin{array}{l}\text { Pre-stressed concrete "T" beams, } 25 \mathrm{~cm} \text { hollow brick pots, } 5 \mathrm{~cm} \\
\text { regularization layer, } 4 \mathrm{~mm} \text { thick cork coating on the floor }\end{array}$ & $1.00 \mathrm{~W} / \mathrm{m}^{2} .{ }^{\circ} \mathrm{C}$ \\
\hline $\begin{array}{l}\text { Interior } \\
\text { pavement }\end{array}$ & $\begin{array}{l}\text { Pre-stressed concrete "T" beams, } 25 \mathrm{~cm} \text { hollow brick pots, } 5 \mathrm{~cm} \\
\text { regularization layer, } 4 \mathrm{~mm} \text { thick cork coating on the floor }\end{array}$ & $0.88 \mathrm{~W} / \mathrm{m}^{2} .{ }^{\circ} \mathrm{C}$ \\
\hline $\begin{array}{l}\text { Horizontal } \\
\text { roof }\end{array}$ & $\begin{array}{l}\text { Pre-stressed concrete "T" beams, } 25 \mathrm{~cm} \text { hollow brick pots, } \\
\text { lightweight expanded clay aggregate (LECA) } 6 \mathrm{~cm} \text { thick, no } \\
\text { insulation, } 4 \mathrm{~cm} \text { regularization layer, fiber cement slabs resting on } \\
\text { small brick walls forming strongly ventilated attic. }\end{array}$ & $1.80 \mathrm{~W} / \mathrm{m}^{2}{ }^{\circ} \mathrm{C}$ \\
\hline
\end{tabular}


Table 2 (continued) - Description of the housing envelope and equipment - Azenha de Cima

\begin{tabular}{llr}
\hline $\begin{array}{l}\text { Envelope / } \\
\text { Equipment }\end{array}$ & Description & $\begin{array}{c}\text { Thermal } \\
\text { transmittance } \\
/ \text { efficiency }\end{array}$ \\
\hline Glazing 1 & $\begin{array}{l}\text { Simple sliding aluminum frames, with single 4mm glazing with } \\
\text { white-colored PVC outdoor blinds }\end{array}$ & $3.9 \mathrm{~W} / \mathrm{m}^{2} .^{\circ} \mathrm{C}$ \\
\hline Glazing 2 & $\begin{array}{l}\text { Anodized aluminum frames with simple glass of 4 mm, without } \\
\text { sunscreen (in the laundry). }\end{array}$ & $6.2 \mathrm{~W} / \mathrm{m}^{2} .^{\circ} \mathrm{C}$ \\
\hline Ventilation & $\begin{array}{l}\text { Natural ventilation (blind boxes, no grids on the facades, no special } \\
\text { sealing devices) }\end{array}$ & $\begin{array}{r}\text { Airflow of } \\
60 \mathrm{~m}^{3} / \mathrm{h} .\end{array}$ \\
\hline $\begin{array}{l}\text { Space heating } \\
\text { pheparation } \\
\text { system }\end{array}$ & Manual or portable electric heaters & Efficiency $=1$ \\
\hline $\begin{array}{l}\text { Dith an efficiency of } 0.39 \\
\text { DHW }\end{array}$ & Efficiency $=0.39$ \\
\hline
\end{tabular}

\section{Results}

The results obtained by design analysis and through a monitoring process are presented below.

\subsection{Energy performance}

To describe the energy performance of dwellings, an energy audit was made for each one, in order to determine its heating and cooling needs, as well as the energy needs for DHW. The type of dwelling according to the number of rooms (T2 means two bedrooms) and the acclimatized floor area of the dwellings $(A u)$, shown in Table 3, were used for calculations, as well as the area of surrounding walls, pavements, roofs and glazing, along with their thermal transmittance or efficiency shown in Tables 1 and 2. These items are used to calculate the average annual needs for heating, cooling and DHW, per square meter of acclimatized area, shown in Figure 1, for the average dwelling.

Table 3 - Description of type of dwelling and acclimatized area - Leça vs. Azenha de Cima

\begin{tabular}{cccccc}
\hline & $\begin{array}{c}\text { Au - acclimatized } \\
\text { floor area }\end{array}$ & $\begin{array}{c}\text { T1 } \\
\text { (Units) }\end{array}$ & $\begin{array}{c}\mathrm{T} 2 \\
\text { (Units) }\end{array}$ & $\begin{array}{c}\text { T3 } \\
\text { (Units) }\end{array}$ & $\begin{array}{c}\text { T4 } \\
\text { (Units) }\end{array}$ \\
\hline Leça (sustainable) & 2,300 & 2 & 10 & 17 & 0 \\
\hline $\begin{array}{c}\text { Azenha de Cima } \\
\text { (traditional) }\end{array}$ & 2,583 & 0 & 20 & 12 & 4 \\
\hline
\end{tabular}

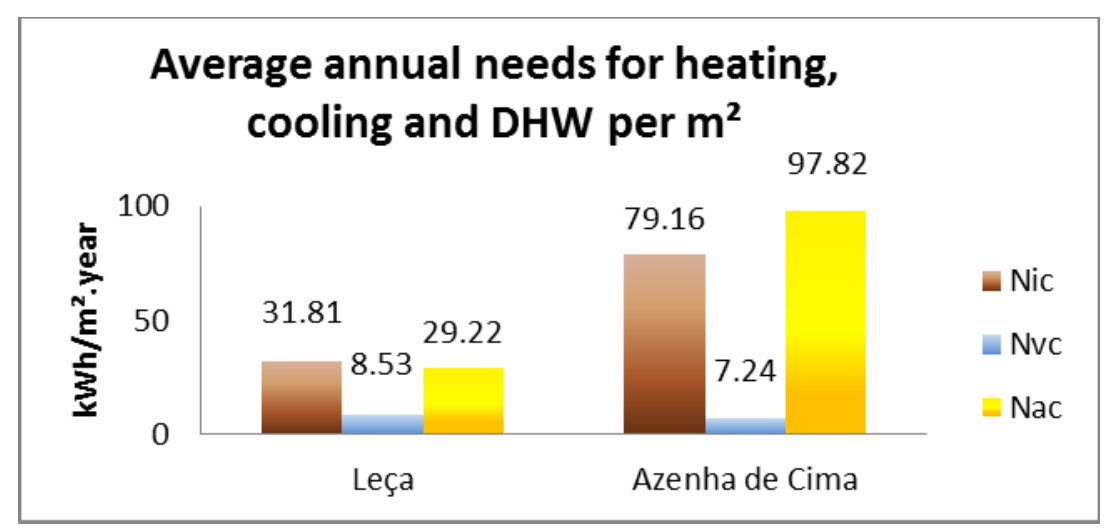

Figure 1 - Average annual needs for heating (Nic), cooling (Nvc) and DHW (Nac) - Leça vs. Azenha de Cima

The items presented in Figure 1, have the following meaning $[6,7,8]$ : 
Nic: Average annual heating needs of electricity to keep the house at $20^{\circ} \mathrm{C}$ during the winter season $\left(\mathrm{kWh} / \mathrm{m}^{2}\right.$.year), per dwelling, for the total dwellings of the building;

$N v c$ : Average annual cooling needs of electricity to keep the house at $25^{\circ} \mathrm{C}$ during the summer $\left(\mathrm{kWh} / \mathrm{m}^{2}\right.$.year), per dwelling, for the total dwellings of the building;

Nac: Average annual DHW energy needs to ensure a daily consumption of 40 liters of hot water per inhabitant in the dwelling, in $\mathrm{kWh} / \mathrm{m}^{2}$.year $(\mathrm{T} 1=2$ inhabitants, $\mathrm{T} 2=3$ inhabitants, $\mathrm{T} 3=4$ inhabitants, $\mathrm{T} 4=5$ inhabitants), per dwelling, for the total dwellings of the building.

From Figure 1 it is possible to conclude that a sustainable construction is prepared to spend $60 \%$ less electricity in space heating and $70 \%$ less natural gas in DHW, per square meter. Considering that the average of a dwelling in Leça is $79.3 \mathrm{~m}^{2}$ and the average areas of a dwelling in Azenha de Cima is $71.8 \mathrm{~m}^{2}$, the annual heating needs and DHW needs for the average dwelling of each building are presented in Table 4 .

These results show that a non-sustainable dwelling can spend, for heating, twice the energy that a sustainable one spends, and is very probable to spend, for the standard comfort, almost seven times more energy in DWH.

Table 4 - Annual energy needs for the average dwelling - Leça vs. Azenha de Cima

\begin{tabular}{ccccc}
\hline & $\begin{array}{c}\text { Average floor } \\
\text { area } \\
\left(\mathrm{m}^{2}\right)\end{array}$ & $\begin{array}{c}\text { Annual heating } \\
\text { needs } \\
(\mathrm{kWh} . \text { year })\end{array}$ & $\begin{array}{c}\text { Annual cooling } \\
\text { needs } \\
(\mathrm{kWh} . \text { year })\end{array}$ & $\begin{array}{c}\text { Annual DHW } \\
\text { needs } \\
(\mathrm{kWh} . \text { year })\end{array}$ \\
\hline Leça (sustainable) & 79.3 & 2,523 & 676 & 2,317 \\
\hline Azenha de Cima (traditional) & 71.8 & 5,684 & 520 & 7,023 \\
\hline
\end{tabular}

The values of Nic, Nvc and Nac mentioned in Figure 1 are quantified using calculation methods included in the Portuguese thermal regulations [7]. Figure 2 shows the average values of annual energy needs per dwelling (Ntc), expressed in kilogram(s) of oil equivalent, as well as their maximum allowable values $(\mathrm{Nt})$. In this figure it is possible to conclude that average annual energy needs in sustainable building of Leça are less than half the maximum allowed and, on the opposite, average annual energy needs in traditional building of Azenha de Cima exceed in 22\% the maximum allowed.

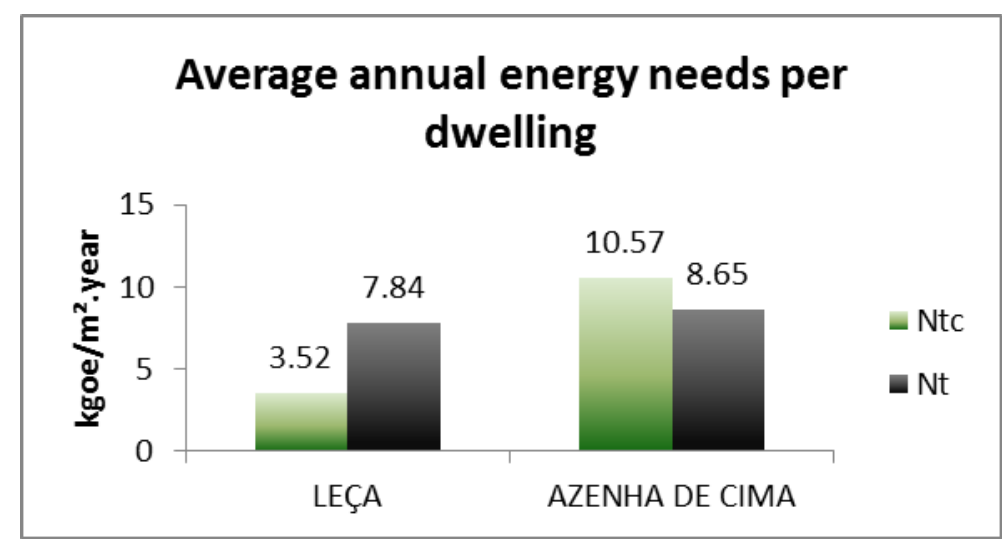

Figure 2 - Average annual energy needs - Leça vs. Azenha de Cima 
Energy needs for each dwelling, expressed in $\mathrm{kgoe} / \mathrm{m}^{2}$.year, are determined according to the needs for heating, cooling and DHW, expressed by the formula:

$$
\mathrm{Ntc}=0,1(\mathrm{Nic} / \eta \mathrm{i}) . \mathrm{F}_{\text {pui }}+0,1(\mathrm{Nvc} / \eta v) . \mathrm{F}_{\text {puv }}+\mathrm{Nac} . \mathrm{F}_{\text {pua }}
$$

In which:

Ntc: Annual primary energy consumption, in kilogram(s) of oil equivalent (kgoe);

$\eta \mathrm{i}, \eta \mathrm{v}$ : Efficiency of equipment for heating and cooling;

$\mathrm{F}_{\text {pui }}, \mathrm{F}_{\text {puv }}, \mathrm{F}_{\text {pua }}$ : Conversion factor of energy used in heating, cooling and DHW to primary energy (electricity: $F_{p u}=0,290 \mathrm{kgoe} / \mathrm{kWh}$; solid, liquid and gas fuels: $F_{p u}=0,086 \mathrm{kgoe} / \mathrm{kWh}$ ).

Relation between Ntc and $\mathrm{Nt}$ is used to determine $\mathrm{CO}_{2}$ emissions and the Efficiency Energy Rating (EER) Label [6]. Energy rating, as normalized by Portuguese Law [6, 7, 8], relates the value of annual primary energy consumption with the maximum allowable annual primary energy consumption, as follows:

\begin{tabular}{|c|c|c|}
\hline $0.00<\mathrm{Ntc} / \mathrm{Nt} \leq 0.25:$ :A+" Class; & $0.25<\mathrm{Ntc} / \mathrm{Nt} \leq 0.50$ : “A” Class; & $0.50<\mathrm{Ntc} / \mathrm{Nt} \leq 0.75: \quad$ "B" Class; \\
\hline 0 . "B-“ Clas & $1.00<\mathrm{Ntc} / \mathrm{Nt} \leq 1.50$ : "Cl" Class; & $1.50<\mathrm{Ntc} / \mathrm{Nt} \leq 2.00:$ " $\mathrm{D}$ " Class; \\
\hline $2.00<\mathrm{Ntc} / \mathrm{Nt} \leq 2.50:$ :E" Class; & $2.50<\mathrm{Ntc} / \mathrm{Nt} \leq 3.00$ : "F" Class; & $\mathrm{Ntc} / \mathrm{Nt}>3,00$ : G Class, \\
\hline
\end{tabular}

In which:

$\mathrm{Nt}$ : Maximum allowable values of annual primary energy consumption (kgoe).

Considering the same regulations, the EER of 23 dwellings of Leça is " $A$ " (the remaining 6 are " $B$ " class) and the EER of the all 36 dwellings of Azenha de Cima is " $C$ ". The " $A$ " label of Leça means that the needs of primary energy for this building are less than $50 \%$ than the maximum needs of primary energy allowed. On the other hand, the "C" class in Azenha de Cima means that the needs of primary energy for this traditional building are higher, up to $50 \%$ more than the maximum needs of primary energy allowed by new regulations.

In order to compare the annual emissions of $\mathrm{CO}_{2}$ of the average dwelling of each building, it is presented its value in Figure 3. It is possible to see that the estimated emissions for the building efficiency are almost three times higher in Azenha de Cima than in Leça.

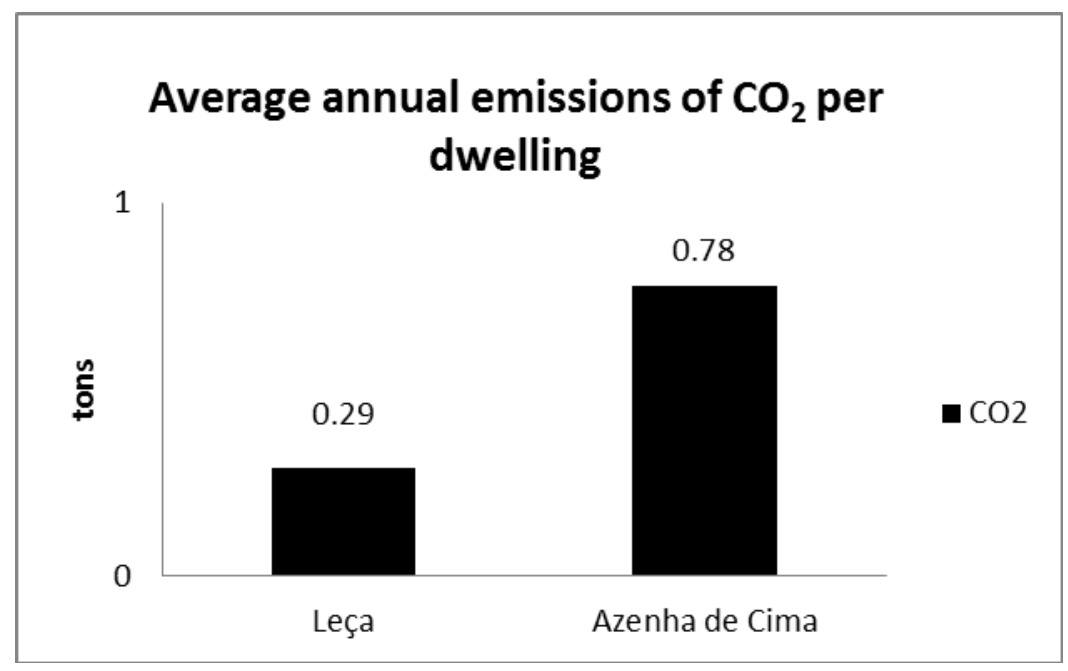

Figure 3 - Average $\mathrm{CO}_{2}$ annual emissions- Leça vs. Azenha de Cima 
According to calculations of global heating, cooling and DHW needs for each building, it is possible to present their values for each building.

These results, calculated for Leça building (sustainable), with 29 dwellings, and for Azenha de Cima building (traditional), with 36 dwellings, are very clear about the importance of thermal insulation, efficient heaters and of use of solar collectors, as shown in Table 5.

Table 5 - Annual energy needs and solar gains - Leça vs. Azenha de Cima

\begin{tabular}{lcccccc}
\hline & $\begin{array}{c}\text { Solar gains } \\
\text { in winter } \\
\mathrm{kWh} / \text { year }\end{array}$ & $\begin{array}{c}\text { Heating } \\
\text { needs in } \\
\text { winter } \\
\mathrm{kWh} / \mathrm{year}\end{array}$ & $\begin{array}{c}\text { Solar gains } \\
\text { in summer } \\
\mathrm{kWh} / \mathrm{year}\end{array}$ & $\begin{array}{c}\text { Cooling } \\
\text { needs in } \\
\text { summer } \\
\mathrm{kWh} / \text { year }\end{array}$ & $\begin{array}{c}\text { Solar gains } \\
\text { in collectors } \\
\mathrm{kWh} / \mathrm{year}\end{array}$ & $\begin{array}{c}\text { DHW needs } \\
\mathrm{kWh} / \text { year }\end{array}$ \\
\hline $\begin{array}{l}\text { Leça } \\
\text { (sustainable) }\end{array}$ & 30,000 & 73,163 & 10,435 & 19,619 & 31,835 & 67,206 \\
\hline $\begin{array}{l}\text { Azenha de Cima } \\
\text { (traditional) }\end{array}$ & 42,490 & 202,139 & 40,062 & 18,548 & $\begin{array}{c}\text { Not } \\
\text { available }\end{array}$ & 250,790 \\
\hline
\end{tabular}

According to Table 5, efficient thermal insulation is responsible for $64 \%$ less energy in heating during winter season; efficient gas heaters and solar collectors are the cause of Leça building spending $73 \%$ less energy in DHW.

As shown in Figure 1 and 2, as well as in Table 4, energy conservation measures strongly reduce the environmental impact from $\mathrm{CO}_{2}$ emissions and energy import dependency. The most effective measures to reduce energy needs are the optimized insulation of external walls and roofs, weatherproof double-glazed windows, the installation of solar collectors and efficient heaters for DHW [21].

\subsection{Energy costs for heating, cooling and DHW}

Based on numerical data from Figure 1, the annual costs (in euro) for the demands of each type of energy were calculated for the Leça average dwelling and for the Azenha de Cima average dwelling, as shown in Table 6 . These costs were obtained taking into consideration the annual heating, cooling and DHW needs and the cost of energy ( $€ 0.19 / \mathrm{kWh}$ of electricity and $€ 0.075 / \mathrm{kWh}$ of natural gas - cost of domestic gas and electricity at the time of the case study - September 2012).

Table 6 - Average expectable energy costs per dwelling - Leça vs. Azenha de Cima

\begin{tabular}{ccccc}
\hline & $\begin{array}{c}\text { Average floor } \\
\text { area } \\
\left(\mathrm{m}^{2}\right)\end{array}$ & $\begin{array}{c}\text { Annual cost for } \\
\text { heating } \\
(\text { euro })\end{array}$ & $\begin{array}{c}\text { Annual cost for } \\
\text { cooling } \\
(\text { euro })\end{array}$ & $\begin{array}{c}\text { Annual cost for } \\
\text { DWH } \\
(\text { euro })\end{array}$ \\
\hline Leça (sustainable) & 79.3 & 479.37 & 128.44 & 173.78 \\
\hline Azenha de Cima (traditional) & 71.8 & $1,080.00$ & 98.80 & 526.73 \\
\hline
\end{tabular}

The estimated annual costs for heating, cooling and water heating obtained for the average dwelling allow, by summing them, to determine its total expense on energy. Therefore, it follows that the expected average annual expenditure on energy for heating, cooling and heating domestic hot water, is, per dwelling, of $€ 781.59$ for the building of Leça and $€ 1,705.53$ for the building of Azenha de Cima.

These costs were calculated for the purpose of maintaining a level of comfort for the residents, with their house heated permanently at $20^{\circ} \mathrm{C}$ during winter season, cooled permanently at $25^{\circ} \mathrm{C}$ during summer and to ensure a daily consumption of 40 liters of hot water per inhabitant in the dwelling. 
But, in opposition to the optimum levels of indoor comfort, involving the costs above mentioned, it is possible to determine the cost actually spent in energy for heating and for DHW, determined by a monitoring procedure, as shown in section 2.3.

\subsection{Monitoring procedure of costs in energy in residential housing cooperative}

For one complete year, the same dwellings presented in section 2.2 were monitored through monthly readings, in what concerns electricity and natural gas consumptions, and their consumptions were registered for further statistic treatment. So, it is possible to show, in the following section, the results of real consumptions of the residents in electricity for heating and natural gas for DHW. There are no results for cooling, because neither dwelling possesses cooling devices.

\subsubsection{Description of energy consumptions in dwellings for heating and DWH}

As shown in Figure 4, real consumptions per square meter of electricity for indoor heating are lower in Leça than in Azenha de Cima dwellings. The reason is that Leça possesses important differences in what concerns thermal insulation, so that residents spend a very limited amount of energy, opposed to the traditional building, which spend more to obtain similar, but minimum, level of comfort.

When comparing Figure 1 and Figure 4, it is possible to understand that, for each type of energy, real consumption is much lower than energy consumption for a standard level of comfort. The reason for this disparity is that the latter values are calculated for standard comfort conditions that are not followed by most residents. The actual comfort conditions are well below those set by legislation.

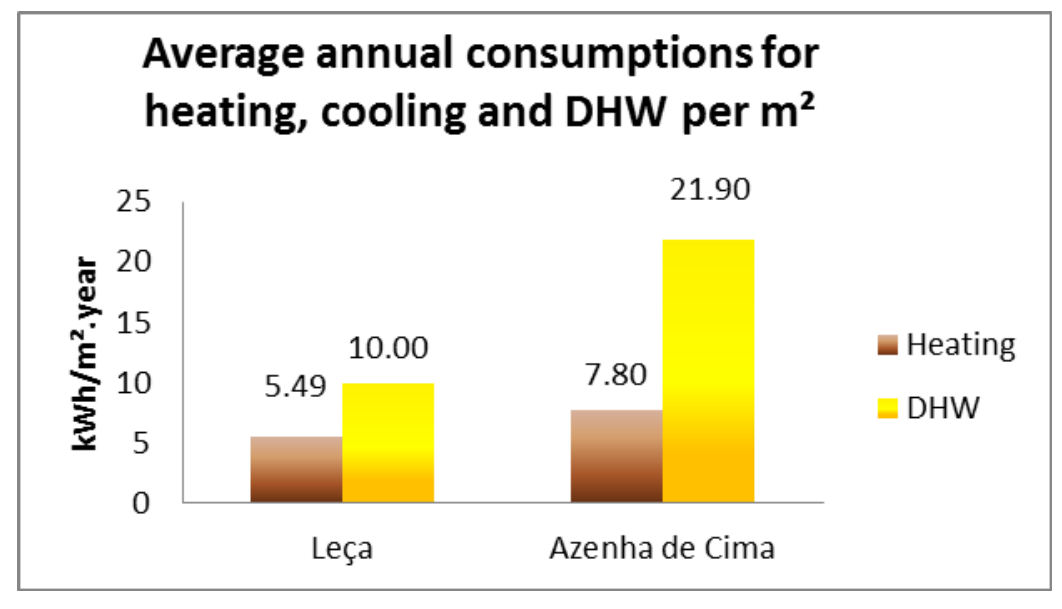

Figure 4 - Average annual consumption for heating and DHW- Leça vs. Azenha de Cima

On the other hand, as the inhabitants of Azenha de Cima do not possess solar collectors or efficient heaters for DHW, they spend almost three times more energy to heat water, per square meter.

The average dwelling of Leça, with lower consumption per square meter, but larger area $\left(79.3 \mathrm{~m}^{2}\right)$ than the average dwelling of Azenha de Cima $\left(71.8 \mathrm{~m}^{2}\right)$, spends less energy in heating per year than the traditional one $-435 \mathrm{kWh}$ against $560 \mathrm{kWh}$. In what concerns DHW, the average sustainable dwelling spends $619 \mathrm{kWh}$ per year and the traditional dwelling spends $1,572 \mathrm{kWh}$ per year, as shown in Table 7.

When comparing Table 7 with Table 4, it is possible to verify that consumptions registered by monitoring on cooperative housing are much lower than the calculated needs of energy expected to maintain a comfortable indoor environment. This is mainly due to the low income of cooperative residents, who cannot afford to spend a higher amount in heating or DHW, and so they limit the use of energy to the minimum. 
Table 7 - Annual consumptions of energy for the average dwelling - Leça vs. Azenha de Cima

\begin{tabular}{cccc}
\hline & $\begin{array}{c}\text { Average floor } \\
\text { area } \\
\left(\mathrm{m}^{2}\right)\end{array}$ & $\begin{array}{c}\text { Annual } \\
\text { consumption } \\
\text { for heating } \\
(\mathrm{kWh} . \text { year })\end{array}$ & $\begin{array}{c}\text { Annual } \\
\text { consumption } \\
\text { for DWH } \\
(\mathrm{kWh} . \text { year })\end{array}$ \\
\hline Leça (sustainable) & 79.3 & 435 & 619 \\
\hline Azenha de Cima (traditional) & 71.8 & 560 & 1,572 \\
\hline
\end{tabular}

\subsubsection{Heating and DHW consumption costs}

Based on numerical data from Figure 3, the annual costs (in euro) for the demands of each type of energy were calculated for the Leça average dwelling and for the Azenha de Cima average dwelling, as shown in Table 8. These costs were obtained taking into consideration the same cost of energy considered in section 2.2.4.

Table 8 - Average real energy costs per dwelling - Leça vs. Azenha de Cima

\begin{tabular}{cccc}
\hline & $\begin{array}{c}\text { Average floor } \\
\text { area } \\
\left(\mathrm{m}^{2}\right)\end{array}$ & $\begin{array}{c}\text { Annual cost for } \\
\text { heating } \\
\text { (euro) }\end{array}$ & $\begin{array}{c}\text { Annual cost for } \\
\text { DWH } \\
\text { (euro) }\end{array}$ \\
\hline Leça (sustainable) & 79.3 & 82.65 & 46.43 \\
\hline Azenha de Cima (traditional) & 71.8 & 106.00 & 118.00 \\
\hline
\end{tabular}

It is possible to verify, by comparing Table 6 with Table 8, that annual costs for heating and DHW registered by monitoring on cooperative housing are much lower than the calculated costs of energy expected to maintain a comfortable indoor environment. The reason is, as mentioned in section 5.3.1, residents only spend in energy the amount of money they can afford.

Cooperative housing, which cost and indoor area cannot exceed the maximum allowed by Portuguese Law, in order to obtain tax benefits equivalent to social housing, has been considered, for several years, as low quality housing. During the last years, an effort has been made to build with higher standards of quality and energy efficiency without increasing the cost of construction.

The result has been a significant increase of indoor comfort while maintaining purchase costs and strongly reducing running costs, as shown on the above figures and tables.

\subsection{Analysis of the results of efficiency studies according to comfort standards}

To analyze the differences in energy demands between a building with sustainable construction characteristics (Leça) and a building with traditional construction features (Azenha de Cima), it is important to examine the main data of these buildings and decide to what extent the data is important to the comparative analysis. According to Table 3, Leça building has just less seven dwellings than Azenha de Cima, which makes the two buildings comparable in what concerns size. When comparing floor areas, Leça building possesses 11\% less area than Azenha de Cima (2,300.00 $\mathrm{m}^{2}$ against 2,583.00 
$\mathrm{m}^{2}$ ). This means that Leça building has in relation to Azenha de Cima building more average floor area per dwelling (79.3 $\mathrm{m}^{2}$ against $71.8 \mathrm{~m}^{2}$ ), which makes housing more comfortable but at the same time, leads to an increase in its envelope area, with a consequent increase in the heat losses and energy needs.

For the analysis, as shown in Table 9, for each building, taking into account that a T1 dwelling has, on average, two persons, a T2 has three persons a T3 has four residents and a T4 has five persons, Leça building contains 102 inhabitants and Azenha de Cima building houses 128 inhabitants. Given that the average number of inhabitants per dwelling in cooperative housing developments is 3.5 , corresponding to an average distribution of types of $10 \%$ for $\mathrm{T} 1,40 \%$ for type $\mathrm{T} 2,40 \%$ for $\mathrm{T} 3$ and 10 $\%$ for $\mathrm{T} 4$, it appears that the average number of residents of Leça building is 3.51 inhabitants per dwelling and the average number of people in the building in Azenha de Cima is 3.56 people per dwelling, so they are equivalent in the average number of people per dwelling. These values are slightly higher than the average population density of cooperative housing developments [11, 13, 22] and configure a cooperative housing density that has an impact on energy consumption in housing, particularly in energy consumption for water heating.

Based on the calculations of energy requirements for winter and summer comfort, as well as for producing hot water, as far as areas, dwellings and inhabitants are concerned, it is possible to draw two main conclusions about the performance and energy efficiency of the dwellings described in Table 10:

- Leça presents a cost of annual energy demand for heating, cooling and DHW, per $\mathrm{m}^{2}$ of floor area, 58.5\% lower than the Azenha de Cima building ( $€ 9.86 / \mathrm{m}^{2}$ against $€ 23.75 / \mathrm{m}^{2}$ ). This difference shows that the choice of households to purchase cooperative housing with sustainable building features, allows savings, for a dwelling with $75.00 \mathrm{~m}^{2}$, of $€ 1,041.75$ per year, equivalent to a monthly average saving of $€ 86.81$;

- Estimated annual energy demand for domestic water heating, per capita, in the Leça building is $66.5 \%$ lower than the estimated annual demand in the Azenha de Cima building ( $€ 49.51$ against $€ 148.00)$. This difference shows that the option for providing energy-efficient equipment, such as solar collectors and high-efficient water heaters, turns into high savings in energy over the lifetime of the building.

Table 9 - Description of areas, dwellings and inhabitants - Leça vs. Azenha de Cima

\begin{tabular}{lcrrr}
\hline & Un & Leça & Azenha de Cima \\
\hline Number of dwellings & Un & 29 & 36 \\
\hline Floor area of all dwellings & $\mathrm{m}^{2}$ & $2,300.00$ & $2,583.00$ \\
\hline Average area of dwellings & $\mathrm{m}^{2} / \mathrm{dw}$ elling & 79.3 & 71.8 \\
\hline Number of inhabitants in buildings & Un & 102 & 128 \\
\hline Average population by dwelling & Un/ dwelling & 3.51 & 3.56 \\
\hline
\end{tabular}

Table 10 - Description of energy demands costs - Leça vs. Azenha de Cima

\begin{tabular}{lcrr}
\hline & Un & \multicolumn{1}{c}{ Leça } & Azenha de Cima \\
\hline Global energy needs & $\mathrm{kWh}$. year & $159,988.00$ & $471,477.00$ \\
\hline Energy needs per $\mathrm{m}^{2}$ of floor area & $\mathrm{kWh} / \mathrm{m}^{2}$. year & 69.56 & 184.22 \\
\hline Annual energy costs per building & $€$ & $22,666.00$ & $41,530.00$ \\
\hline Annual energy costs per $\mathrm{m}^{2}$ of floor area & $€ / \mathrm{m}^{2}$ & 9.85 & 23.75 \\
\hline Annual energy cost for water heating per capita & $€ /$ person & 49.51 & 148.00 \\
\hline
\end{tabular}




\subsection{Analysis of the results of efficiency studies according to monitored consumptions}

As mentioned before, energy consumptions obtained by monitoring are lower than energy needs to maintain standard levels of comfort. Using the same data areas, number of dwellings and number of residents, it is possible to describe energy costs obtained from consumptions, as shown in Table 11, and compare them with energy needs for standard comfort, as presented in Table 10. An exception is made for costs for cooling, because neither dwelling possesses cooling devices.

Table 11 - Description of energy consumption costs - Leça vs. Azenha de Cima

\begin{tabular}{lcrr}
\hline & Un & Leça & Azenha de Cima \\
\hline Global energy consumption & $\mathrm{kWh}$. year & $35,627.00$ & $76,715.00$ \\
\hline Energy consumption per $\mathrm{m}^{2}$ of floor area & $\mathrm{kWh} / \mathrm{m}^{2}$.year & 15,49 & 29.70 \\
\hline Annual energy consumption costs per building & $€$ & $4,124.13$ & $8,070.00$ \\
\hline $\begin{array}{l}\text { Annual energy consumption costs per } \mathrm{m}^{2} \text { of } \\
\text { floor area }\end{array}$ & $€ / \mathrm{m}^{2}$ & 1.79 & 3.12 \\
\hline $\begin{array}{l}\text { Annual energy consumption } \\
\text { heating per capita }\end{array}$ & $€ /$ forson & 16.91 & 33.15 \\
\hline
\end{tabular}

Based on data from energy consumptions for heating during winter season, as well as for producing domestic hot water, it is possible to draw two main conclusions:

- In what concerns heating and DHW, residents of Leça spend $46.4 \%$ of the Azenha de Cima. High-efficient thermal insulation, together with solar gains, efficient solar collectors and gas heaters provide acceptable indoor comfort in Leça dwellings. On the other hand, Azenha de Cima residents use sun exposure to gain as much heat as possible, as presented in Table 5, to compensate the lack of insulation and maintain a minimum indoor comfort in this building;

- The existence of solar collectors and efficient gas heaters does reduce energy consumption for water heating. These savings, which remain during the life cycle of the building, are extremely important in what concerns running costs - similar occupation of the average dwelling provides an annual saving of $€ 0.75$ per square meter of natural gas for this purpose.

\subsection{Payback period of sustainable construction}

This study shows that it is possible to measure cost benefits in sustainable cooperative construction. It is expected that a sustainable cooperative dwelling spends on electricity and natural gas, per year and per square meter, $€ 13.90$ less [23.75 - 9.85] than a dwelling of traditional cooperative construction, considering standard levels of comfort. This difference is due mainly to an envelope highly-efficient and also to the use of efficient solar collectors and gas heaters.

Consulting technical and financial data of Leça project, it is possible to present a list of highlyefficient materials and equipment, as well as their costs, which are described in Table 12. As none of these materials and equipment was used in Azenha de Cima project, it is possible to assume that the values shown in Table 12 represent the increase of costs associated to the implementation of sustainable construction features.

The costs of these materials and equipment, for the 29 dwellings, were calculated in $€ 73,095.59$. This means that the cost of sustainable construction in Leça building, per dwelling, is of $€ 31.78$ per square meter. Assuming that a sustainable building of Leça spends less $€ 13.90$ per square meter and 
per year than the traditional building of Azenha de Cima, the payback period is of $€ 31.78 / € 13.90=$ 2.3 years.

The efficient solution for DHW needs, on itself, has a similar payback period. According to results as shown in Table 9, the cost for a complete system of solar collectors and efficient gas heater for the 29 dwellings is $€ 30,452.92$, or $€ 13.24$ per square meter. It is possible to calculate the medium cost, per square meter and per year, of the annual DHW energy needs expected to both buildings, which is of $€ 2.20$ for the Leça building and of $€ 7.34$ for the Azenha de Cima building. Savings of $€ 7.34$ $€ 2.20=€ 5.14$, by using solar collectors and efficient gas-heaters, are payable in $€ 13.24$ / $€ 5.14=2.6$ years. The building systems and efficient equipment included in this list led to the " $\mathrm{A}$ " and " $\mathrm{B}$ " classes of efficiency of the dwellings in Leça building.

Table 12 - Cost of efficient materials and equipment of Leça project and payback period for sustainable construction with standard comfort energy consumptions

\begin{tabular}{lr}
\hline & Cost $(€)$ \\
\hline Thermal insulation in façades & $14,816.48$ \\
Thermal insulation in interior walls & $2,423.68$ \\
Thermal insulation in interior floors & $2,381.98$ \\
Thermal insulation in roofs & $6,005.15$ \\
Windows of low permeability to the wind & $3,975.40$ \\
Double glazing with 12mm air gap & $6,360.64$ \\
Permanent mechanical ventilation and air inlet grids & $6,679.34$ \\
High-efficient gas heater & $5,800.00$ \\
Complete system of solar collectors & $24,652.92$ \\
\hline Total costs of efficient materials and equipment for 39 dwellings & $73,095.59$ \\
Increase of cost per square meter due to efficient construction & 31.78 \\
Savings in energy consumption per m ${ }^{2}$ and per year due to efficient & 13.90 \\
construction & 2.3 years \\
Payback period for efficient construction &
\end{tabular}

In what concerns monitored consumptions, knowing that the use of sustainable construction has lower running costs in energy, when compared with traditional construction, as shown in Table 11, it is also possible to calculate its payback period for a level of acceptable comfort for cooperative residents. This payback period, higher than the one calculated for standard comfort is, nevertheless, smaller than the life cycle of the building, as shown in Table 13.

Table 13 - Payback period for sustainable construction with low but acceptable energy consumptions

\begin{tabular}{lr}
\hline & Cost $(€)$ \\
\hline $\begin{array}{l}\text { Increase of cost per square meter due to efficient construction } \\
\text { Savings in energy consumption per } \mathrm{m}^{2} \text { and per year due to efficient } \\
\text { construction }\end{array}$ & 31.78 \\
$\begin{array}{l}\text { Payback period for efficient construction for minimum but acceptable } \\
\text { consumptions }\end{array}$ & $\mathbf{2 4}$ years \\
\hline
\end{tabular}

The above payback periods are considered to be the lower and the higher limits of an interval where the payback period should fit, according to the level of comfort chosen by the residents. In other words, the higher level of comfort in heating, cooling and using DHW, in their dwellings, the lower would be the payback period, and vice-versa. 


\section{Conclusions and recommendations}

This study points to a positive development of cooperative housing, when using sustainable construction. This positive impact is achieved due to the following main factors:

- Firstly, it is considered that general reduction of heat loss through construction elements, as is usually considered by designers, is not sufficient; it is recommended to optimize efficiency of the inner and outer envelope [19]. According to the data shown in Tables 10, 11 and 12, the cost increase by using very efficient techniques of insulation of the envelope is $4.2 \%$ of the construction cost and the decrease of heat loss achieved varies from 30\% (according to consumptions) to 60\% (according to energy needs) when compared with traditional construction. These results are similar to those obtained in other studies about optimization of energy in residential buildings [23];

- Moreover, it is recommended the inclusion of solar collectors and water gas heaters of high efficiency in the design, since the increase of cost using these devices, when compared with standard ones, is small taking into account the decrease of energy use they provide. According to the data shown in Tables 5, 6 and 9, the increase of cost by using solar collectors and efficient gas heaters is $1.8 \%$ of the construction cost and the decrease of cost in using DHW achieved varies from $46 \%$ (according to consumptions) to $70 \%$ (according to energy needs) when compared with traditional construction;

- Furthermore, it is possible to conclude that the inclusion in design of efficient techniques of insulation of the envelope, solar collectors and water gas heaters, has a payback period that varies between 2.3 to 24 years, according to the level of comfort used by residents in their dwellings.

However, the most positive impact of this study is that it is possible to build sustainable construction under controlled costs, i.e. with low costs. In fact, it is common to think that, to reach a high Energy Efficiency Rating, houses and apartments should contained sophisticated, efficient but expensive equipment. But, in this study, it is shown that it only needs an average increase of $4.2 \%$ in construction cost to achieve sustainable characteristics, so, this study is not only applicable to cooperative housing under controlled costs but also to social housing.

Cooperative housing is targeted at lower and mid-lower class, who cannot afford buying expensive residences. In this study, made by using a sample of 65 low cost cooperative dwellings, it is possible to prove that sustainable construction can be equally efficient, with high EER label, done at low cost. This type of construction provides an average increase of $€ 31.79$ per square meter over the cost of traditional construction, and also provides annual savings in indoor heating, indoor cooling and DHW between $€ 1.33$ and $€ 13.90$ per square meter.

But, despite these positive results, we must continue to broaden the studies concerning the quantification of maintenance and operating costs related to the techniques and systems used, including its social and economic impact on the savings of economic resources of the families living in cooperative ventures during the lifetime of the building. Finally, taking into account the current conjuncture, it should be noted that the adoption of these and other practices for the sustainable use of resources and housing represents an individual commitment and an economical and social inevitability. 


\section{References}

1. J. Mourão, J. B. Pedro, Sustainable Housing: from consensual guidelines to broader challenges, in Portugal SB 07 Sustainable Construction, Materials and Practices. Amsterdam: IOS Press, 2007.

2. B. Edwards, Guía Básica de la Sostenibilidad, third ed., Editorial Gustavo Gili, Barcelona, 2005.

3. A. Coelho, A promoção de habitação cooperativa com qualidade e custos controlados, in: Encontro Nacional sobre Qualidade e Inovação na Construção - QIC 2006, LNEC, Lisboa, 2006, pp. 21-24.

4. S. Halliday, F. Stevenson, Sustainable Construction and the Regulatory Framework, Gaia Research, 2004, http://www.gaiagroup.org/Research/IDS/suc-con-reg/SCRFsummary.pdf

5. S. Halliday, Sustainable Construction, first ed. reprinted, Burlington: Butterworth-Heinemann, Elsevier, Oxford, 2009.

6. Decree-Law Nr. 78/2006, Energy Certification and Indoor Air Quality in Buildings, Portuguese legislation, Lisbon (Portugal), April 4th, 2006.

7. Decree-Law Nr. 80/2006, Regulation of the Thermal Behaviour Characteristics in Buildings, Portuguese legislation, Lisbon (Portugal), April 4th, 2006.

8. Directive 2002/91/CE, Directive of the European Parliament and of the European Council, on the Energy Performance of Buildings, EPBD, Brussels, Belgium, December 12th 2002.

9. M. Pinheiro, Será que a sustentabilidade na construção é mais onerosa?, in Actas do Congresso de Inovação na Construção Sustentável (CINCOS’08), 2008, centrohabitat@centrohabitat.net

10. S. Roaf, M. Fuentes, S. Thomas, Ecohouse, third ed., Elsevier Architectural Press, Oxford, 2007.

11. F. Arnaldo, O. Magano, Habitação Cooperativa em Portugal 1974-1991, FENACHE, Federação Nacional de Cooperativas de Habitação Económica, Porto, 1992.

12. I. Santos, L. Soares, J. Teixeira, Guidelines for a good practices manual on sustainable construction, Portugal SB 07 Sustainable Construction, Materials and Practices, Part II, IOS Press, Amsterdam, 2007.

13. NORBICETA, The First Cooperative Development of Sustainable Housing in Portugal, Germina, Lisbon, 2007.

14. Law Nr. 85/98, Tax Cooperative Statute, Portuguese legislation, Lisbon (Portugal), December 16th, 1998.

15. Outrequin, P. SHE Project Assessment Reports, The EU SHE project "Sustainable Housing in Europe", Rome, 2006.

16. C. Kibert, Sustainable Construction, Green Building Design and Delivery, John Wiley and Sons, Inc. second ed., Hoboken, New Jersey (USA), 2008.

17. C. Santos, Thermal Transmittance Values for Elements of Building Envelope, ITE50, LNEC, Lisbon (Portugal), 2007.

18. E. Strother, W. Turner, Thermal Insulation Building Guide, Robert Krieger Publishing Company, Inc., Malabar, Florida, USA, 1990.

19. Bolattürk, A., Optimum insulation thicknesses for building walls with respect to cooling and heating degree-hours in the warmest zone of Turkey, Building and Environment, Vol. 43 (6), pp. 1055-1064, June, 2008.

20. R. Nicholls, The Green Building Bible, The Low Energy Design Technical Reference. fourth ed. Vol. 2, Llandysul: Green Building Press, 2008, pp. 43-46.

21. Ballaras C. et al, European residential buildings and empirical assessment of the Hellenic building stock, energy consumption, emissions and potential energy savings, Building and Environment, Vol. 42 (3), pp. 1298-1314, March 2007. 
22. A. Lusardi, The role the co-operative housing sector can play in combating climate change, in: The EU SHE project "Sustainable Housing in Europe" - bridging the gap between theory and practice, Assembly for Cymru Wales, 2007, http://www.assemblywales.org/

23. Ihm, P., Krarti, M., Design optimization of energy efficient residential buildings in Tunisia, Building and Environment, Vol. 58 (9), pp. 81-90, December 2012. 